\title{
Blended-Learning Berbasis Guided-Inquiry Pada M ata Kuliah IPS di Era Pandemi
}

\author{
Pamungkas Stiya M ulyani \\ Universitas Sains Al-qur'an Jawa Tengah, Indonesia \\ pamungkasstiyamulyani@gmail.com \\ Salis I rvan Fuadi \\ Universitas Sains Al-qur'an Jawa Tengah, Indonesia \\ irvan@unsiq.ac.id
}

\begin{abstract}
The purpose of this research is to find out how to prepare learning as a solution for social science lectures during a pandemic, providing an overview for educators to provide effectively and solution learning. This research uses a type of classroom action research by adopting the MCK erman model with the research stages: Stages of Problem Description, Needs Analysis, Hypothesis of ideas, Action Plan, Plan Implementation, Evaluation, Decision Making, Stages of Conclusion, and Publication. It is concluded that the instrument has been tested for validation by an expert validator and received input and revision orders by the validator and everything has been done and has been declared valid with very good criteria. This has an impact on the results of student responses wherein the second cycle has increased.
\end{abstract}

Keywords: Blended L earning, Guided Inquiry, pandemic period 


\begin{abstract}
Abstrak
Penelitian ini bertujuan untuk mengetahui bagaimana mempersiapkan pembelajaran sebagai solusi perkuliahan pembelajaran IImu Pengetahuan Sosial (IPS) secara daring ditengah pandemi COVID 19, memberikan gambaran kepada pada pendidik untuk memberikan pembelajaran yang solutif dan efektif pada pandemi COVID 19. Penelitian ini menggunakan jenis penelitian tindaan kelas dengan mengadobsi model McKerman dengan tahapan peneltiannya adalah: Penjabaran Masalah, Analisis Kebutuhan, Hipotesis gagasan, Action Plan, Implementasi Rencana, Evaluasi, Pengambilan Keputusan, Tahapan kesimpulan dan publikasi. T ahapan tersebut dilaksanakan setidaknya dalam dua siklus tindakan Berdasarkan penelitian yang telah dilaksanakan dapat disimpulkan bahwa Instrumen telah dilakukan uji validasi oleh validator ekspert dimana instrumen mendapat masukan dan perintah revisi oleh validator dan semuanya telah dilakukan dan telah dinyatakan valid dengan kretria sangat baik. selanjutnya dalam penerapanya bahwa melalui instrumen peneliti memperoleh informasi bahwa pada siklus pertama pada prosesnya implemntasi masih terdapat kendala dari berbagai sumber baik dari dosen pengampu maupun mahasiswa, namun pada siklus kedua semua kelemahan pada siklus pertama dapat diatasi dengan baik, hal ini juga berimbas pada hasil respon mahasiswa dimana pada siklus kedua mengalami peningkatan.
\end{abstract}

Kata kunci: Blended-Learning, Guided-Inquiry, Pandemi

\title{
A. Pendahuluan
}

Covid 19 memberikan dampak diberbagai sektor kehidupan manusia seperti ekonomi, pariwisata, sosial dan yang tidak kalah pentingnya adalah pendidikan. Sejak ditetapkan darurat covid 19 pemerintah mengharuskan untuk tidak adanya pembelajaran dikelas, seluruh aktifitas pembelajaran yang tadinya dilaksanakan tatap muka langsung kini berganti dengan pembelajaran tatap muka daring seiring dikeluarkan peraturan pemerintah melalui kementrian pendidikan dan kebudayaan pada tanggah 24 Maret 2020 nomer 4 tahun 2020 tentang pelaksanaan kebijakan pendidikan dalam masa darurat penyebaran covid 19 (W. A. F. D ewi 2020), dalam edaran tersebut dijelaskan bahwa pembelajaran dilaksanakan dengan model daring/jarak jauh. Dosen dituntun melakukan perubahan kebiasaan perkuliahan dari tatap muka langsung menjadi tatap muka jarak jauh, hal ini menuntut D osen untuk menjadi solutif dan inovatif supaya tujuan perkuliahan tetap berjalan dengan lancar. Ditambah fasilitas pendukung perkuliahan daring yang belum siap secara material. Ini menjadikan dosen untuk dapat memanfaatkan fasilitas yang ada dan dipadukan dengan perkembangan teknologi yang 
sudah ada, diantaranya fasilitas jaringan internet, wifi, atau internet dari provider penyedia jasa komunikasi. Namun permasalahannya tidak semua tempat atau wilayah pengguna memiliki jaringan yang stabil atau membutuhkan kuota data yang besar untuk dapat menjalankan aplikasi.

Dosen juga perlu memilih dan memilah aplikasi yang sesuai dan efektif diterapkan dan dapat diterima oleh mahasiswanya, salah satunya adalah aplikasi whatsapp, google classrom dan google form. Dimana aplikasi ini tidak terlalu membutuhkan banyak kuota untuk menjalankannya, ditambah aplikasi ini mudah dalam pengoprasiannya. $\mathrm{N}$ amun aplikasi yang yang tepat pun kurang efektif jika penerapan model pembelajarannya tidak sesuai. Blended learning berbasis guided inquiry adalah salah satu solusi yang tepat untuk mengatasi permasalahan ini. Blended learning sendiri adalah pembelajaran dengan menggabungkan pembelajaran tatap muka dengan pembelajaran online (Sari 2014), pada dasarnya pembelajaran ini telah lama adanya namun di Indonesia pembelajaran ini tergolong relatif baru, hal ini tidak lepas dengan perkembangan dan kemudahan akses teknologi informasi yang masuk ke Indonesia.

Faktor lain yang harus diperhatikan adalah dampak dari tuntutan perubahan pola hidup dan kerja, tidak terkecuali dalam proses perkuliahan mahasiswa. Penulis melihat pola perkuliahan yang terlaksana di lapangan adalah pola konvensional tradisional, dimana pembelajaran berlangsung dengan $100 \%$ hanya tatap muka dan dibatasi dengan waktu berdasar bobot sks di setiap mata kuliah, serta peran teknologi komunikasi dan informasi yang tidak menjadi satu kesatuan dalam proses perkuliahan. Lebih lanjut bahwa terdapat anggapan di kalangan dosen mengenai dalam satu minggu pembelajaran tatap muka sudah sesuai dengan aturan pembelajaran yang ada, indikator pembelajaran yang baik adalah berdasar berapa jumlah pertemuan tatapmukanya (Dikti 2014). Hal ini, harus perlu dipikirkan dengan membiasakan perkuliahan yang merujuk pada perkembangan Industri 4.0

Kebiasaan proses perkuliahan mata kuliah IImu Pengetahuan Sosial (IPS) sangat tergantung pada pertemuan tatap muka langsung, tukar informasi dan tanya jawab serta aturan mengikuti ujian akhir semua ditentukan dari pertemuan tatap muka, kebiasaan ini akan menjadikan rasa canggung dan kurang pahamnya mahasiswa jika komunikasi dilaksanakan melalui media eletronik seperti whatsapp atau sejenisnya, bahkan hal tersebut menjadikan salah persepsi dan timbul konfik, hal ini dikarenakan kadang ada kalanya mahasiswa tidak mengetahui apakah ini hal serius atau bercanda. Kebiasaan ini menjadikan mahasiswa menjadi kurang cepat dalam menerima informasi dan menanggapinya sehingga mahasiswa dapat ketinggalan informasi dari semakin cepatnya perkembanagn industri 4.0 ini. Di sisilain banyak 
mahasiswa sebagai kaum milineal selain sibuk menjalankan kewajibannya sebagai mahasiswa mereka juga menggeluti bidang lain yang dapat mendatangkan keuntungan dan mengasah bakatnya, seperti berbisnis di bidang fasion, kuliner, barang eletronik dan kegiatan positif lainnya. Jika kebiasaan pembelajaran konvensional diterapkan mereka dapat mengalami hambatan dalam mengembangkan diri mahasiswa. untuk itu perlu dibiasakan pola pembelajaran yang dapat mengikuti perkembangan zaman dan informasi teknologi, serta dapat diterima semua pemahaman mahasiswa. yaitu melalui pembelajaran blended learning berbasis guided inquiry. Dimana pembelajaran ini tidak hanya terfokus pada pertemuan tatap muka saja namun juga pembelajaran online yang memanfaatkan perkembangan dan kecanggihan teknologi informasi pada saat ini. M elalui model guided inquiry mahasiswa dapat secara luas bereksplorasi dan menggali potensi diri secara totalitas dengan cara mereka sendiri. U ntuk itu perlu adanya pembiasaan mahasiswa dengan pola perkuliahan yang menyesuiakan dengan perkembangan zaman, terlebih dalam era pandemi saat ini, dimana pembalajaran tatap muka langsung belum diperbolehkan. $\mathrm{Hal}$ ini akan menjadikan sulit bagi mahasiswa dan dosen yang sudah terbiasa dengan pembelajaran tatap mula langsung (Zafi and Falasifah 2019).

Banyak penelitian terdahulu yang menunjukan keefektifan blended learning. Pada penelitian (Pramesti 2016) diperoleh hasil penelitian bahwa 75.3\% siswa merespon dengan baik tentang penerapan pembelajaran blended learning untuk meningkatkan aktivitas belajar siswa, penelitian ini menggunakan instrumen data yang telah tervalidasi dengan rata rata berkatagori baik. Keefektifan blended learning di tingkat mahasiswa juga ditunjukan oleh penelitian (C. A. Dewi 2013) dimana blended learning dapat meningkatkan hasil belajar mahasiswa dan juga meningkatkan kemampuan afektif mahasiswa. Pembeda antara penelitian yang telah dilakukan dan penelitian ini adalah siswa atau mahasiswa sudah disiapkan materi dan apa saja yang harus dilaksanakan oleh siswa atau mahasiswa, sehingga siswa atau mahasiswa hanya tinggal menjalankan saja, diskusi tanya jawab hanya sekedar pertanyaan siswa atau mahasiswa yang kurang paham saja. Sedangkan pada penelitian ini dengan menggunakan guided inquiry mahasiswa hanya diberi gambaran dan arah materi yang akan dibahas, selebihnya mahasiswa mengeksplore pengetahuannya sehingga daya kreatifitas dan insiatif mahasiswa dapat terbangun, dalam diskusi dalam grub banyak muncul pertanyaan yang dapat menambah pengetahuan, pemahaman dan analisis kritis mahasiswa. sehingga pengemabnagn karakter pada mahasiswa dapat semakin baik. $\mathrm{H}$ al ini diperkuat oleh penelitian ( $\mathrm{H}$ ayat, Erwin, and Permana 2018), dimana berdasarkan hasil evaluasi perkuliahan bahwa pembelejaran blended learning dapat berdampak adanya pembelajaran yang berlanjut. Ini menunjukan adanya pengaruh positif dari blended learning dalam hubungannya dengan keberlanjutan untuk pembelajaran selanjutnya. Penerapan blended learning dimasa pandemi covid 19 
terkendala pada pertemuan tatap muka langsung yang tidak dapat dilaksanakan, untuk itu dapat disiasati dengan bantuan aplikasi, antara lain dengan, google classroom, atau google meet dan untuk online sepanjang waktunya menggunakan aplikasi whatsapp.

(Wardoyo 2013) yang mengutip pendapat Feletti menyatakan pembelajaran berbasis inquiry merupakan sebuah pembelajaran yang berorientasi pada pembelajaran yang bersifat inquiry fleksibel (flexinguiry), mencari dan menemukan kesimpulan yang bersumber dari beranekaragam keterampilan dan sumber belajar yang didalamnya termasuk ada pendekatan pembelajaran interdisiplin serta pemecahan masalah, asumsi bertanggung jawab, dan berfikir kritis terhadap pembelajaran siswa itu sendiri . Pembelajaran inquiry terbimbing memudahkan mahasiswa untuk melaksanakan pembelajaran mandiri, dosen membimbing dan mengarahkan mahasiswa untuk menemukan pengetahuannya. Pembelajaran ini sangat cocok bila diterapkan saat pandemi covid 19 ini, pembelajaran inquiry menjadikan seorang dosen tidak perlu menerangkan materi sampai akhir kepada mahasiswa, mahasiswa memiliki pengetahuan awal yang diperoleh dari proses inquiry praktis, dan memanfaatkan pada masalah di dunia nyata, memecahan masalah merupakan proses alami yang akan ditimbulkan dari temuan siswa (Wenning 2010). Dengan bantu aplikasi yang ada sekarang ini dosen dapat melakukan pembimbingan dan pemantauan terhadap mahasiswa.

Berdasar uraian diatas dijelaskan bahwa tujuan penelitian ini adalah untuk mengetahui bagaimana mepersiapkan mempersiapkan pembelajaran sebagai solusi perkuliahan pembelajaran IImu Pengetahuan Sosial (IPS) secara daring ditengah pandemi. Yaitu dari bagaimana menganalisis kebutuhan dilapanganan, proses pembuatan perangkat pembelajaran, instrumen pengamatan serta cara menganalisis dan juga implikasi pelaksanaan pembelajaran yang diterapkan. $\mathrm{Hal}$ ini didasarkan dari analisis kebutuhan awal yang dilakukan peneliti dengan mengobservasi baik dari dosen dan mahasiswa, serta kesulitan dalam penyesuaian model perkuliahan baru yang dijalankan pada saat masa pandemi covid 19 ini. Banyak dosen dan mahasiswa yang belum siap karena belum terbiasa dengan pola ini, dan apa saja yang harus disiapkan dalam melaksanakan model pembelajaran di era pandemi ini.

Penelitian ini menggunakan jenis penelitian tindaan kelas (Classroom Action Research) dengan mengadobsi model McKerman dengan tahapan peneltiannya adalah: Tahapan penentuan variabel, M eminta izin, M erancang skema penelitian dan mempersiapkan instrumen penelitian, Penjabaran Masalah, Analisis Kebutuhan, Hipotesis gagasan, Action Plan, Implementasi Rencana, Evaluasi, Pengambilan Keputusan, Tahapan kesimpulan dan publikasi. T ahapan tersebut dilaksanakan setidaknya dalam dua siklus tindakan. Pengumpulan informasi dilakukan dengan $\mathrm{H}$ asil Angket, $\mathrm{H}$ asil Q uisioner, $\mathrm{H}$ asil Lembar Pengamatan, serta 
observasi tidak tertulis oleh peneliti dan dosen. Teknik analisis yang digunakan adalah mendeskripsikan secara kualitatif dan menarasikannya serta mentabulasikan setiap hasil informasi setelah dilakukan sintesis dan selajutnya dilakukan penyajian dan pengambilan kesimpulan (Kusuma and D witagama 2010). Dan penelitian ini dilaksanakan dalam dua kali siklus penelitian. Penelitian dilaksanakan pada program studi pendidikan guru madrasah ibtidaiyah Universitas Sains Al-Qur'an semester empat di tahun 2020 pada matakuliah Ilmu Pengetahuan Sosial (IPS).

\section{B. Pembahasan}

Perencanaan dimulai dari pemikiran langkah yang akan dilaksanakan hingga bagaimana teknik dan bentuk pembelajaran yang akan dijalankan, serta penyusunan indikatorindikator pembelajarannya Bersumber dari diskusi perencanaan oleh penulis, dosen dan pakar pendidikan yang tuntun dengan pengisian quisioner oleh Dosen pengampu matakuliah, peneliti dan observer supaya topik pembicaraan tidak melenceng jauh dari indikator diperoleh bahwa dalam mata kuliah IImu Pengetahuan Sosial, permasalahan pembelajaran bukan hanya bersumber dari mahasiswa saja, dimana mahasiswa kurang dalam mencari referensi informasi baik secara tekstual maupun secara online, mahasiswa gemar untuk membuka internet namun mereka enggan berupaya mengejar referensi untuk materinya. Selain itu terkendalanya mahasiswa dalam memiliki sumber belajar seperti laptop maupun smart phone juga mencari salah satu faktor penghambat mahasiswa, disamping ketersediaan paket data atau jaringan wifi untuk mengakses informasi dan materi. $N$ amum faktor yang tidak kalah penting adalah peran dosen dalam membuka komunikasi yang bagus kepada mahasiswa. Terlebih pada situasi pandemi Covid ini dimana kedua belah dituntut untuk saling support satu sama lain.

Selain itu pada masa sekarang yang berbarengan dengan Era revolusi industry 4.0 saat ini mahasiswa di tuntut untuk dapat lebih dalam mengembangkan potensi diri serta dapat bersaing dan mengalahkan keadaan yang ada, untuk itu bekal dan pengembangan keterampilan yang berkarakter sebagai dari hasil luaran pembelajaran sangatlah penting di banding hanya aspek koqnitif saja. Berdasar referensi dan informasi serta diskusi tim peneliti, teman sejawat serta pakar pendidikan disetujui bahwa keterampilan dasar yang harus di miliki oleh mahasiswa sebagai bekal mereka dalam mengikuti persaingan di era revolusi industry 4.0 adalah kemampuan komunikasi yang bagus dan bagaimana mereka bekerja sama, untuk itu karakter ini harus menjadi luaran wajib yang harus dapat dimunculkan mahasiswa selelah mengikuti perkulihan media teknologi informasi. $\mathrm{H}$ asil dari proses pembelajaran ini yang akan di amati 
dalam penelitian ini selain mereka juga dapat menciptakan produk teknologi yang kekinian sesuai dengan perkembangan dan kebutuhan zaman (Rosmayanti 2020).

Adapun teknis ketika melaksanakan pembalajran blended learning adalah sebagai berikut : 1) M embuat SAP Matakuliah IImu Pengetahuan Sosial (IPS) menggunakan model pembelajaran blended learning berbasis guided inquiry serta membuat grub diskusi melalui aplikasi whatsapp untuk media komunikasinya. 2) grub whatsapp beranggotakan mahasiswa dan setiap grub terdiri dari 5 mahasiswa mahasiswa yang menempuh matakuliah IImu pengetahuan sosial, hal ini digunakan untuk mempermudah pengawasan dan kontrol, sehingga dosen mudah dalam memberikan pembimbingan.

Pertemuan pertama berisi mengenai penjelasan dosen tentang gambaran materi yang akan dipelajari dalam satu semester kedepan pada matakuliah IPS. H arapan dari output atau hasil perkuliahan yang di peroleh di akhirnya, memberikan tugas pada setiap masing masing kelompok dan menjelaskan point point penting disetiap penugasannya, bagiamana cara berdiskusi dalam grub whatsapp dan digunakan dalam proses kegiatan perkuliahan. Dalam pelaksanaannna yang dikalukan tetap melaksanakan protokol kesehatan pandemi covid 19 yang dianjurkan oleh pemerintah, sehingga dalam prosesnya tetap menggunakan applikasi lain yaitu google duo dan meeting, dan sebelum dilaksanakan perkulihan daring mahasiswa diwajibkan untuk menyiapkan materi dan bahan diskusi, mahasiswa yang melaksanakan aktif diskusi mendapatkan point tersendiri dari dosen. dan setelah pelaksanaan selama dua siklus pembelajaran dilakukan refkesi untuk melihat dampak positif yang dihasilkan

Pelaksanaan perencanaan perkuliahan pada tahapan berikutnya adalah dilakukan pembuatan instrumen untuk melihat keterlaksanaan perkuliahan, instrumen yang disiapkan antara lain adalah: 1) Lembar pengamatan observer. 2) lembar observasi dosen dan pengamat, 3) angket respon mahasiswa yang berguna untuk melihat feed back dari mahasiswa. Namun sebelum digunakan dalam peneltian semua instrumen dilakukan uji validitas oleh 3 validator ekspert dimana tiap validator memiliki spesifikasi keahlian yang berbeda, seperti ahli materi, ahli pendidikan, dan ahli evaluasi.

Indikator lembar pengamatan observer disesuaikan dengan tahapan tahapan inquiry terbimbing menurut (Jufri 2013) adapun indikator lembar pengamatan observer dapat dilihat pada T abel 1. 
Tabel 1. indikator lembar pengamatan observer

\begin{tabular}{clc}
\hline Kegiatan & \multicolumn{1}{c}{ Indikator yang di amati } & $\begin{array}{c}\text { N omer } \\
\text { ertanyaan }\end{array}$ \\
\hline Pendahuluan & Pengidentifikasian M asalah & 1 \\
\hline & $\begin{array}{l}\text { M engembangkan tujuan atau hipotesis yang } \\
\text { bersifat tentative }\end{array}$ & $2,3,4$ \\
\hline Kegiatan Inti & $\begin{array}{l}\text { M engumpulkan data dan informasi dan } \\
\text { selanjutnya menguji secara tentative }\end{array}$ & $5,6,7$ \\
\hline & $\begin{array}{l}\text { M enyajikan data dan informasi, selanjutnya } \\
\text { mengembangkan kesimpulan dan } \\
\text { menggenaralisasikan }\end{array}$ & 8 \\
\hline Penutup & $\begin{array}{l}\text { Menguji, menerapkan, dan merevisi kesimpulan } \\
\text { M ereview kegiatan perkuliahan yang telah } \\
\text { dilaksanakan }\end{array}$ & 11 \\
\hline & $\begin{array}{l}\text { M enyimpulkan hasil perkuliahan yang telah } \\
\text { dilaksankan }\end{array}$ & 12 \\
\hline &
\end{tabular}

Sedangkan untuk indikator lembar observasi dosen dan pengamat mengacu pada tahapan penelitian tindakan kelas yang mengadopsi model McKerman, adapun indikatornta dapat dilihat pada tabel 2 .

Table 2. Indikator quisioner observer dan dosen

\begin{tabular}{lll}
\hline \multirow{2}{*}{ Kegiatan } & \multicolumn{1}{c}{ Indikator yang di amati } & $\begin{array}{c}\text { N omer } \\
\text { pertanyaan }\end{array}$ \\
\hline \multirow{3}{*}{ Perencanaan } & Pemetaan M asalah & 1 \\
\cline { 2 - 3 } & Analisis K ebutuhan & 2 \\
\cline { 2 - 3 } & Perumusan Action Plan & 3 \\
\cline { 2 - 3 } & FGD Action Plan & 4 \\
\cline { 2 - 3 } Implementasi & Validasi Action Plan & 6 \\
\hline & $\begin{array}{l}\text { Kemantapan diri implementasi } \\
\text { Sesuai Sintaks pembelajaran }\end{array}$ & 7 \\
\hline & $\begin{array}{l}\text { Analisis kendala implementasi } \\
\text { pembelajaran }\end{array}$ & 7 \\
\hline
\end{tabular}




\begin{tabular}{|c|c|c|}
\hline & $\begin{array}{l}\text { Analisis umpan balik implementasi } \\
\text { baik dari suasana kuliah, } \\
\text { lingkungan dan pribadi mahasiswa }\end{array}$ & 8 \\
\hline \multirow{2}{*}{ Evaluasi } & $\begin{array}{l}\text { Koreksi dan capaian diri dalam } \\
\text { melaksanakan pembelajaran }\end{array}$ & 9 \\
\hline & $\begin{array}{l}\text { Solusi pemecahan masalah dan } \\
\text { implementasi Pembelajaran }\end{array}$ & 10 \\
\hline Kesimpulan & Penyimpulan & 11 \\
\hline
\end{tabular}

Dari instrumen tersebut telah dilakukan uji validasi oelh validator ekspert dengan hasilnya dapat dilihat pada tabel 3 dan 4.

Tabel 3. H asil Validasi Lembar pengamatan 0 bserver

\begin{tabular}{|c|c|c|}
\hline \multirow{2}{*}{ No } & \multirow{2}{*}{ Aspek yang dinilai } & Validator \\
\hline & & 123 \\
\hline 1 & Keterkaitan pertanyaan dengan tujuan & $\begin{array}{lll}3 & 4 & 4\end{array}$ \\
\hline 2 & Kesesuaian pernyataan dengan indikator. & $\begin{array}{lll}3 & 3 & 4\end{array}$ \\
\hline 3 & Kesesuaian antara pernyataan dengan tujuan & $\begin{array}{lll}4 & 4 & 4\end{array}$ \\
\hline \multirow[t]{5}{*}{4} & Bahasa yang digunakan & $\begin{array}{lll}3 & 4 & 4\end{array}$ \\
\hline & Jumlah skor & 44 \\
\hline & N ilai & $91,66 \%$ \\
\hline & Kriteria & Sangat \\
\hline & & \\
\hline
\end{tabular}

H asil rekapitulasi validasi Lembar pengamatan 0 bserver menunjukan kriteria angket sangat baik, sehingga sudah layak untuk digunakan. Validator memberi masukan pada Lembar pengamatan 0 bserver ini supaya untuk memperjelas jenis kegiatan pembelajaran pada saat daring tatap muka dan online, dan validator yang lain memberi saran sudah sesuai. dan untuk hasil validasi dari validator ekspert untuk quisioner dosen dan pengamat dapat dilihat pada table 4. 
Tabel 4. Hasil Validasi quisioner dosen dan pengamat

\begin{tabular}{|c|c|c|}
\hline \multirow{2}{*}{ No } & \multirow{2}{*}{ Aspek yang dinilai } & Validator \\
\hline & & 12 \\
\hline 1 & Keterkaitan pertanyaan dengan tujuan & 43 \\
\hline 2 & Kesesuaian pernyataan dengan sintaks & 34 \\
\hline 3 & Kesesuaian antara pernyataan dengan tujuan & 344 \\
\hline 4 & Bahasa yang digunakan & 34 \\
\hline & Jumlah skor & 44 \\
\hline & N ilai & $91,66 \%$ \\
\hline & Kriteria & $\begin{array}{l}\text { Sangat } \\
\text { baik }\end{array}$ \\
\hline
\end{tabular}

Hasil rekapitulasi validasi quisioner dosen dan pengamat menunjukan criteria quisioner dosen dan pengamat sangat baik, sehingga sudah layak untuk digunakan. Validator memberi masukan pada quisioner dosen dan pengamat ini supaya untuk menyedehanakan bahasa yang digunakan supaya mudah dipahami, dan validator yang lain memberi saran sudah sesuai.

Setelah dikatakan valid intrumen-instrumen tersebut digunakan untuk pengambilan data dalam perkuliahan dimasa pandemi covid 19, yang dilaksanakan secara daring/ tatap muka jarak jauh sebagai pengganti pertemuan tatap muka langsung dengan menggunakan aplikasi google meet dan google classroom sementara untuk aplikasi onlinenya menggunakan whatsapp serta mahasiswa, dosen dan pengamat mengisi angket dan lembar pengamatan serta quisioner melalui google form. Dari penggunaan instrumen diperoleh informasi bahwa, pada angket quisioner dosen dan pengampat pada siklus pertama bahwa proses perencaan dosen telah dilakukan dengan matang, dari pemetaan masalah dan dosen serta pengamat telah mampu memberikan gambaran pada tahap demi tahap yang akan dilaksanakannya dan solusi pemecahan masalahnya. Dan untuk tahap implementasi didapat informasi mengenai pelaksanaan pembelajaran yang dilakukan oleh dosen pengampu berdasarkan lembar pengamatan pelaksanaan pembelajaran telah sesuai dengan arah dan tujuan yang harus dicapai yang tercantum dalam RPS dan SAP, baik dari materi yang diberikan, tahap tahap pelaksanaan pembelajaran yang telah sesuai jadwal pembelajaran, serta dosen telah memberikan penguatan 
berupa motivasi kepada mahasiswa. Pada pelaksanaan pembelajaran siklus pertama menurut observer sesuai dari lembar pengamatan, masih kurang responsifnya dosen kepada mahasiswa, masih terasa ada jarak antara dosen dan mahasiswa, sehingga dosen masih merasa canggung dalam memberikan motivasi kepada mahasiswa serta dalam menangani tingkah polah mahasiswa dalam berdikusi dan mengondisikannya, dosen lebih banyak melakukan tidakan pasif serta kurang memberikan bimbingan dan pemantauan pada diskusi grub di whatsapp dan google class room. Berdasarkan analisis keadaan, informasi ini terjadi dikarenakan dosen juga memperlukan penyesuaian dengan teknis pembelajaran yang mungkin baru untuk dirinya, dan hal lain dosen kurasng komunikatif mengenai bentuk produk yang diharapkan sebagai hasil dari perkuliahan kepada mahasiswa, sehingga mahasiswa masih cenderung bingung. $\mathrm{Hal}$ ini berimbas pada saat mahasiswa melakukan presentasi, mahasiswa masih belum dapat memberikan gambaran mengenai produk yang dihasilkan kelebihan dan kekuranganya, menjelaska secara terperinci, dan bagaimana dia melakukan presentasi dan yang paling fatal adalah mereka masih bingung apa yang harus dipresentasikan.

Kesulitan-kesulitan yang di alami oleh dosen pengampu dalam menjalankan proses pembelajaran blended inquiry saat siklus pertama ialah dosen masih belum familier dengan model yang dijalankannya sehingga belum terjadi totalitas dalam pembelajaran, ditambah karean era pandemi pembelajaran tatap muka dilakukan secara daring dengan bantuan aplikasi google duo dan google class room, kurang terjadinya komunikasi antara dosen dan mahasiswa, karena keduanya saling seolah olah menjaga jarak mereka, sehingga menjadikan mahasiswa kurang dalam memberikan tanggapan dan atusiasme saat berdiskusi dalam grub baik dalam whatsapp, dan saat kelompok lain ada yang sedang melakukan presentasi melalui google class room atau duo, mahasiswa lainnya cenderung diem dan idem, selain itu dosen cenderung kurang respon dan kontrol pada saat melakukan pengawasan, sehingga mahasiswa yang mengalami kesulitan dan bingung akan menimbulkan kegaduhan dan komunikasi liar dalam grub. Dan hal yang sangat memperngaruhi adalah keadaan sinyal jaringan internet yang kurang bagus, terlebih menggunakan aplikasi seperti duo dan google class room yang mengharuskan siswa unggah dokumen dan video call saat presentasi, yang membutuhkan kualitas sinyal yang bagus, terlebih pada daerah daerah pelosok yang diluar jangkauan sinyal internet. Serta kurangmya kesadaran mahasiswa dalam mencari reverensi dimana mereka hanya mengcopy paste milik teman atau hanya melihat reverensi dari blog orang yang kurang jelas atau di ragukan kebenaran materinya. Serta kurangnya menggunakan bahasa yang komunikatif pada saat presentasi, sehingga mahasiswa lain kurang dapat memahami maksud dari mahasiswa yang melakukan presentasi. Selain itu kurangnya bahan atau materi presentasi yang menjadikan proses pembelajaran kurang bermakna. 
Pada dasarnya pengaturan mekanisme pembelajaran sudah sangat lengkap dan matang, skema pembelajaran dan hal-hal yang diperlukan sudah disiapkan semua, respon dan antusiasme mahasiswa juga sangat baik, walau ada tiga mahasiswa yang masih cenderung apatis dengan model baru ini. $N$ amun respon mahasiswa belum dapat betul betul terarah pada pembelajaran dan topik yang sedang di bahas. Diskusi juga masih banyak bercandanya peran dosen belum sepenuhnya dapat membawa suasana mahasiswa dalam diskusi yang menarik dan mengendalikan arah diskusi. Secara garis besar dengan model pembelajaran blended learning berbasis guided inquiry ini mahasiswa mengalami perbedaan semangat dalam menerima pembelajaran, karena mahasiswa merasa hal yang baru, mekansime pembelajaran yang baru, mahasiswa sangat antusias dan menerima dengan senang hati pembelajaran ini, meskipun tujuan inti dari pembelajaran ini belum dapat tercapai. M ahasiswa senang dapat berinteraksi dalam lingkup materi perkuliahan dimana tempat dan kapanpun walau mereka tidak bertemu secara langsung.

Hasil dari siklus kedua menunjukan lebih sigapan dosen dalam melakukan perencanaan, memalui koordinasi dengan mahasiswa dan dosen pakar untuk mencari solusi kendala kendala pada siklus pertama, dan mendapatkan gambaran pemecahan yang lebih efektif. Sedangnkan pada tahap implemntasi pelaksanaan pembelajaran pada siklus kedua ini berlangsung selama tiga pertemuan tatap muka secara daring atau selama tiga minggu, dan selama jeda antar pertemuan mahasiswa melakukan kuliah secara online dengan media whatsapp yaitu selama enam hari. Dalam kurun waktu ini dosen melakukan tindakan kelas sesuai dengan hasil diskusi dan arahan pakar. Tindakan tersebut juga di amati oleh pengamat dengan mengisikan lembar pengamatan yang hasilnya berupa informasi sebagai data penelitian. Adapun informasi hasil dari pengamat adalah bahwa dosen telah melaksanakan secara maksimal baik sejak tahap Pengidentifikasian $M$ asalah hingga sampai $M$ enyimpulkan hasil perkul iahan yang telah dilaksankan, baik saat daring maupun online.

Siklus kedua sudah ada perubahan ke arah yang lebih baik setelah dilakukan evaluasi dan pematapan rencana perlakuan pada siklus kedua, walau tidak semua mahasiswa berkatagori baik atau sangat baik semua namun jika dibandingkan dengan siklus pertama sudah mengalami peningkatan. $\mathrm{H}$ anya saja mahasiswa yang masih tetap berpredikat kurang baik untuk lebih dperhatikan supaya bisa dilakukan pengobatan untuk menjadi baik atau sangat baik atau dosen lebih dapat menggali potensi dan keterampilan yang dimiliki mahasiswa tersebut sehingga dosen dapat memilih atau mengembangkan metode belajar yang cocok untuk seluruh mahasiswa dengan keaneka ragaman keterampilan yang dimiliki masing masing mahasiswa. 
Pada pelaksanaan pembelajaran, dosen sudah melaksanakan perannya dengan sangat baik, dari membangun bentuk komunikasi yang baik, responsif dan tanggap kepada kesulitan mahasiswa, selalu memantau dan mendampingi mahasiswa dengan sepenuh hati, serta membimbing dan mendampingi mahasiswa dalam menemukan pengetahuannya dengan baik, baik saat perkulihaan daring maupun offline. Menanggapi pertanyaan mahasiswa dan memberikan pertanyaan pertanyaan balik kepada mahasiswa yang dapat memancing mahasiswa untuk berfikiri dan menemukan jawabannya atau pengetahuannya. Mamncing kepada grub diskusi yang dapat memancing terjadinya diskusi yang berbobot, selain itu dosen juga memberikan bantuan kuota internet untuk memperlancar pembelejaran kepada mahasiswa yang membutuhkan.

Sehinggga dalam menghadapi persaingan dan tuntutan era revolusi industri 4.0 saat ini mahasiswa sudah siap dengan bekal keterampilan yang matang dari yang mereka miliki dan mereka tonjolkan. Pada perlakuakn penelitian ini Mahasiswa juga dibekali untuk mereka tanggap terhadap perkembangan trend saat ini, mahasiswa dibekali dengan produk yang memiliki nilai jual, ini mengubah paradikma pembelajaran tradisional dimana hasil pembelajaran mahaiswa hanya kemampuan kognitif mahasiswa dan tugas sebagai latian. $\mathrm{N}$ amun pada pembelajaran ini mahasiswa dituntut untuk dapat terjun langsung dalam membuat produk yang dibutuhan oleh pasar sehingga memiliki nilai jual, hal ini menjadikan mahasiswa memiliki tambahan skill berwirausaha. Dan ini adalah sesuai dengan tujuan dari revolusi industri 4.0 .

(Yusnaini and Slamet 2019) juga menyatakan tujuan pendidikan pada era revolusi industri 4.0 adalah menuju perubahan pola fikir, cara belajar dan bagaimana cara bertindak oleh siswa atau mahasiswa dal am mengembangkan kemampuan kreatif dan inovatifnya dalam berbagai bidang. $D$ an hal ini dapat menekan angka pengangguran di Indonesia terutama dapam pasar global. $\mathrm{H}$ al ini juga merupakan bagian dari tujuan pembelajaran blended learning berbasis guided inquiry dimasa pandemi ini, dimana dengan menanfaatkan teknologi yang ada tantangan dan harapan hasil pembelajaran pada era revolusi industri 4.0 dapat dimunculkan sekaligus penerapan model pembelajaran ini dapat menjawab kendala pelaksanaan pembelajaran pada era Pandemi ini. Karena pada dasarnya pada era dik=gital ini sangat penting peran tenaga pendidik yang semakin komples dan melengkapi dengan perkembangan zaman ini, serta sangat diharapkan penanganan bentuk perkembangan yang pesat dari pemikiran generasi milenial saat ada di dalam kelas. Ini adalah bentuk motivasi yang sangat penting untuk stimulus munculnya pendidik di era pandemi yang cerdas dan melek teknologi. 
Revolusi pembelajaran pada era revolusi industri 4.0 ini dan kebetulan pada saat era pandemi ini secara garis besar telah menggambungkan antara pengetahuan, tehnologi, teknik tepat gunadan matematis serta berfikir secara internet, dan yang tak bisa terpisahkan adalah pembelajaran sepanjang hayat. Untuk itu blended learning dan inquiry terbimbing adalah solusi dari itu semua. Blended learning memberikan arah pembelajaran yang tidak hanya terbatas pada ruang dan waktu saja, namun bisa dlaksanakan diluar jam pembelajaran dosen dan mahasiswa bisa melakukan komunikasi bimbingan dan diskusi saat diluar pembelajaran, dan metode inquiry terbimbing menjadikan dalam proses pembelajaran mahasiswa dibimbing hingga mereka dapat menemukan pengetahuannya, hasil pemikirannya sendiri dan pembelajaran ini dilakukan secara terus menerus. Pembelajaran inquiry sendiri adalah pembelajaran yang bersifat mandiri, yaitu siswa dapat melakukan mandiri dan bebas merancang dan memilih cara untuk memperoleh pengetahuannya sehingga mahasiswa di tuntut aktif dalam pembelajaran ini.

Perbandingan informasi dari respon mahasiswa pada siklus pertama dan kedua bahwa Pada dasarnya dari rekap keseluruhan siklus pertama dan kedua pada penelitian tindakan kelas ini telah adanya peningkatan kearah yang lebih baik pada siklus kedua hal ini terlihat pada jumlah prosentase total keterampilan. Pada siklus pertam untuk kategori sangat baik memperoleh prosentase global $46,35 \%$ sementara pada siklus kedua memperoleh $46,83 \%$ dan untuk kategori baik pada siklus pertama $42,77 \%$ dan untuk siklus kedua mengalami peningkatan $46,52 \%$ dan untuk kategori kurang baik dari 9,62\% menjadi $6,64 \%$ dan sangat kurang baik dari 1,24\% menjadi $0 \%$. Ini menunjukan adanya perubahan ke arah yang lebih baik dari siklus satu ke siklus kedua.

Bedasarkan uraian data hasil penelitian yang di himpun, diperoleh informasi mekanismpe persiapan pembelajaran blended learning berbasis guided inquiry untuk pembelajaran dimasa pandemi ini telah sesuai dengan padangan (Darmadi 2010) yang menyatakan Perencanaan pengajaran sebagai teknologi adalah suatu perencanaan yang mendorong penggunaan teknik -teknik yang dapat mengembangkan tingkah laku kognitif dan teori-teori konstruktif untuk menemukan solusi terhadap problem-problem pengajaran. Dalam kasus ini, permasalahan yang dihadapi oleh dosen adalah bagaimana dapat melakukan pembelajaran di era pandemi seperti sekarang ini. D osen di tuntut untuk berfikir solutif dalam memecahkan permasalahan ini sehingga menajdi dasar gagasan terciptanya model pembelajaran blended learning berbasis guided inquiry ini, dengan tetap mengikuti pedoman prosedur penelitian pengembangan. Dari hasil penelitian diperoleh informasi mahasiswa akan merasa lebih nyaman mengungkapkan pendapatnya, beserta memberikan alasan alasan 
argumentasinya dengan lebih leluasa, tanpa merasa malu atau canggung, karena dalam hal ini perkuliahan dengan model pembelajaran guded inquiry menjadikan mahasiswa satu dengan yang lain serta dosen mengajar berada pada tempat yang berbeda, hal ini dapat menambah rasa percaya diri mahasiswa dalam mengungkapkan pendapatnya. ini juga pernah di sampaikan oleh (Sadikin and Hamidah 2020), diperoleh informasi dari hasil penelitian yang khas dari penelitian ini adalah mahasiswa lebih merasa nyaman ketika menyampaikan pendapatnya dan gagasannya serta lebih aktif bertanya ketika proses pembelajaran daring, karena mengikuti pembelajaran dari rumah menjadikan mereka tidak merasa memperoleh tekanan psikologis dari teman lainnya seperti yang mereka alami saat pembelajaran offline. Dengan tidak melihat dosen secara langsung menjadikan mereka lebih percaya diri dan tidak canggung dalam menyampaikan pendapatnya, dengan tidak bertemu secara fisik langsung menjadikan mahasiswa merasa lebih nyaman dalam berdiskusi bertukar ide dan gagasan, saling menyanggah dan menguatkan satu sama lain.

( Herliandry et al. 2020) menyatakan mengajar secara daring memberikan efektifitas dan kemudahan dalam proses tukar informasi dalam berbagai situasi dan kondisi. Banyak macam manfaat dan kemudahan di tambah dibantu dengan banyaknya aplikasi yang dapat menejbatani pembelajaran daring ini, dari hasil peneltian ini diperoleh bahwa kondisi mudah dalam tranfer informasi dalam berbagai kondisi dan situasi tidak dapat tercipta dengan begitu saya, perlu proses dan penyesuaian, pengaturan, pengontrolan oleh dosen pada tiap waktu proses pembelajarannya, karena dengan interaksi terlalu lama mengginakan media online ternyata menyebabkan mahasiswa dapat menjadi bosan juga, untuk itu perlu adanya trik khusus supaya mahasiswa tetap dapat fokus pada permasalaahn diskusi dan materi kuliah.

\section{Kesimpulan}

Berdasarkan dari hasil penelitian tindakan kelas yang telah dilaksanakan, dapat simpulkan bahwa persiapan blended learning berbasis guided inquiry sebagai solusi perkuliahan daring era pandemi covid19 telah dilakukan dengan langkah langkah yang telah sesuai, dimana proses pembuatan perangkat perkuliahan, dan pembuatan instrumen perkuliahan sebagai kontrol dalam pembelajarannya. Instrumen telah dilakukan uji validasi oleh validator ekspert dimana instrumen mendapat masukan dan perintah revisi oleh validator dan semuanya telah dilakukan dan telah dinyatakan valid dengan kretria sangat baik.

Selanjutnya dalam penerapanya bahwa melalui instrumen peneliti memperoleh informasi bahwa pada siklus pertama pada prosesnya implemntasi masih terdapat kendala dari berbagai sumber karena belum terbiasanya baik dosen dan mahasiswa dalam model 
pembelajaran ini, hal ini dikarenakan kebiasaan dosen menggunakan metode konfensional dimana perkuliahan lebih banyak dihabiskan dengan pertemuan tatap muka, dosen juga kurang dalam emmantau dan mendampingi diskusi dalam grub whatsapp, dosen hanya memantau di awal dan akhir saja sementara dalam prosesnya dosen kurang memperhatikan, sehingga diskusi yang terjadi dalam grub online tidak terfokus pada materi dan permasalahan dan cenderung banyak mahasiswa yang hanya menyimak, dan juga bergurau membuat pernaytaan yang bernada candaan. Sedangkan pada piham mahasiswa mahasiswa juga sedikit canggung di awal proses pembelajaran, mahasiswa belum memahami betul konsep dan arah pembelajaran yang di inginkan oleh dosen. M ahasiswa lebih banyak menyimak, dan cenderung diam meskipun belum paham dengan materinya, mahasiswa juga lebih suka mencari referensi yang berasal dari blog bukan dari sumbernya langsung. $N$ amun pada siklus kedua semua kelemahan pada siklus pertama dapat diatasi dengan baik, hal ini juga berimbas pada hasil respon mahasiswa dimana pada siklus kedua mengalami peningkatan.

\section{U capan Terima Kasih}

Telah diselesaikannya. D engan terselesaikan artikel hasil penelitian ini, penulis mengu artikel jurnal ini, kami mengucapkan terimakasih yang sebesar besarnya kepada DRPM Kementerian Risetek Dikti atas bantuan dana hibah penelitian D osen pemula dengan nomer kontrak A.07/LP3M-PDP/2020 sehingga artikel jurnal penelitian ini dapat terselesaikan dengan baik.

\section{DAFTAR PUST AKA}

Darmadi, Hamid. 2010. “Kemampuan Dasar Mengajar.” Bandung: Alfabeta: 114.

Dewi, Citra Ayu. 2013. "Pengaruh Blended Learning Dalam Pembelajaran Berbasis Masalah (PBL) Terhadap Hasil Belajar Mahasiswa IKIP Mataram Pada Materi Pencemaran Lingkungan." Prisma Sains: Jurnal Pengkajian IImu dan Pembelajaran Matematika dan IPA IKIP M ataram 1(1): 1-11.

Dewi, Wahyu Aji Fatma. 2020. "Dampak Covid-19 Terhadap Implementasi Pembelajaran Daring Di Sekolah Dasar.” Edukatif: Jurnal IImu Pendidikan 2(1): 55-61.

Dikti. 2014. "Buku Panduan Kurikulum Pendidikan Tinggi." : 50-60.

Hayat, Muhammad Syaipul, Erwin Erwin, and Irvan Permana. 2018. "Strategi Evaluasi Program Perkuliahan Biologi Berbasis Blended Learning." JURNAL BIOEDUKATIKA $5(2): 65-72$.

H erliandry, Luh D evi, N urhasanah N urhasanah, M aria Enjelina Suban, and H eru Kuswanto. 
2020. “Pembelajaran Pada M asa Pandemi Covid-19." JTP-jurnal Teknologi Pendidikan 22(1): 65-70.

Jufri, Wahab. 2013. "Belajar Dan Pembelajaran Sains." Bandung: Pustaka Reka Cipta.

Kusuma, Wijaya, and Dedi Dwitagama. 2010. "Mengenal Penelitian Tindakan Kelas, Jakarta: PT."

Pramesti, Ni Made Galih Arya. 2016. "Pengaruh Penerapan Model Pembelajaran Blended Learning Untuk Meningkatkan Aktivitas Belajar Siswa Kelas X TKJ.” IT-Edu: Jurnal Information Technology and Education 1(02).

Rosmayanti, Ervi. 2020. "Upaya Penggunaan Model Pembelajaran Jarak Jauh U ntuk Meningkatkan Aspek Spiritual Siswa SD 2 Medini." A/ H ikmah: Journal of Education $1(1): 85-92$.

Sadikin, Ali, and Afreni Hamidah. 2020. "Pembelajaran Daring Di Tengah Wabah Covid19:( O nline Learning in the M iddle of the C ovid-19 Pandemic)." Biodik6(2) : 214-24.

Sari, Milya. 2014. "Blended Learning, Model Pembelajaran Abad Ke-21 Di Perguruan Tinggi." Ta'dib 17(2).

Wardoyo, Sigit Mangun. 2013. "Research Based Learning." Jakarta: A kademia.

Wenning, Carl J. 2010. "Levels of Inquiry: U sing Inquiry Spectrum Learning Sequences to Teach Science." Journal of Physics T eacher education online 5(4) : 11-20.

Yusnaini, Yusnaini, and Slamet Slamet. 2019. "Era Revolusi Industri 4.0: Tantangan Dan Peluang Dalam U paya Meningkatkan Literasi Pendidikan." In Prosiding Seminar Nasional Program Pascasarjana Universitas PGRI Palembang, .

Zafi, Ashif Az, and Firda Falasifah. 2019. "Model Pembelajaran Quantum Teaching Pada Mata Pelajaran PAI Di SDN Purworejo 02 Pati." JURNAL AL-QALAM: JURNAL KEPENDIDIKAN 19(2): 1-12. 
